
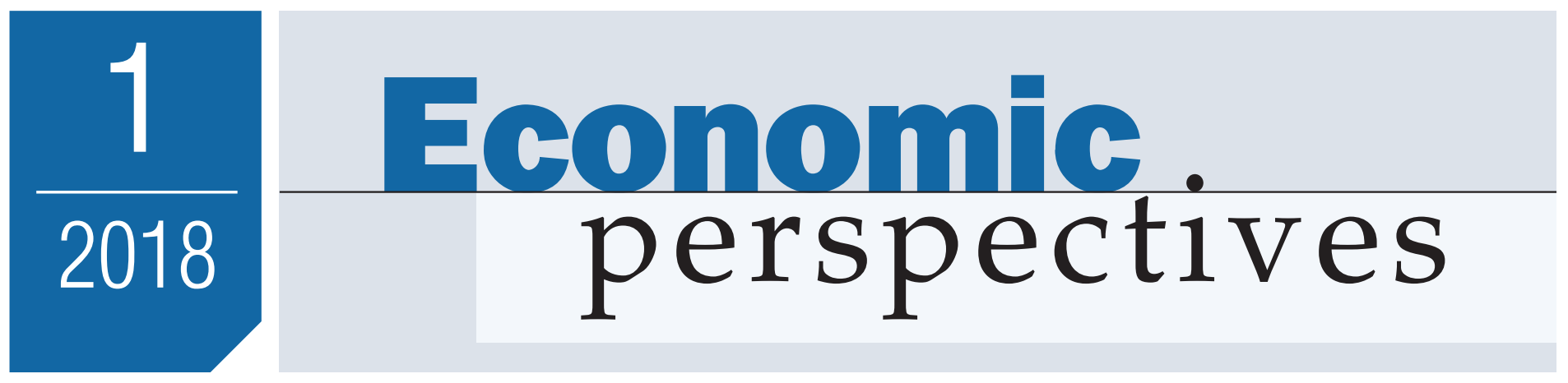

https://doi.org/10.21033/ep-2018-1

\title{
Household inequality and the consumption response to aggregate real shocks
}

Gene Amromin, Mariacristina De Nardi, and Karl Schulze

\section{Introduction and summary}

The drop in output and consumption that occurred during the Great Recession has been large and prolonged. Figure 1 displays per capita U.S. real gross domestic product (GDP) and personal consumption expenditures (PCE) between 1985 and 2016 and highlights the large drop in both consumption and output that occurred starting in 2007 and its parallel shift compared with the previous trend. In this article, we ask why consumption has dropped so much and has been recovering so slowly. We also ask to what extent household inequality before and after the Great Recession interacted with the recession itself to generate such a large and persistent drop in consumption. ${ }^{1}$

To reach our goal, we first review two key papers, Krusell and Smith (1998) and Krueger, Mitman, and Perri (2016), and summarize what we understand from quantitative macro models with aggregate uncertainty about wealth inequality, borrowing-constrained households with heterogeneous marginal propensities to consume (MPCs), and the response of aggregate consumption to an aggregate shock. The key message from macroeconomic theory is that the extent to which households are borrowing constrained (which in these models means how many people have low wealth holdings) and how that changes both over time and with aggregate shocks are crucial to explaining the aggregate economy's response and the speed of its recovery. That is, versions of these models with a realistic fraction of poor people can generate larger consumption drops in response to a total factor productivity (TFP) shock than models with fewer poor people. Hence, inequality does affect aggregate consumption dynamics in response to shocks in an important way.

While these two papers, Krusell and Smith (KS) and Krueger, Mitman, and Perri (KMP), provide very important lessons and are much more realistic than previous models, we argue that these newer models still abstract from important changes that happened during the Great Recession and are thus likely to understate the size (and potentially the persistence) of the consumption drop that occurred and the role of household inequality in generating it. 
FIGURE 1

\section{U.S. real per capita GDP, PCE, and their linear trends}

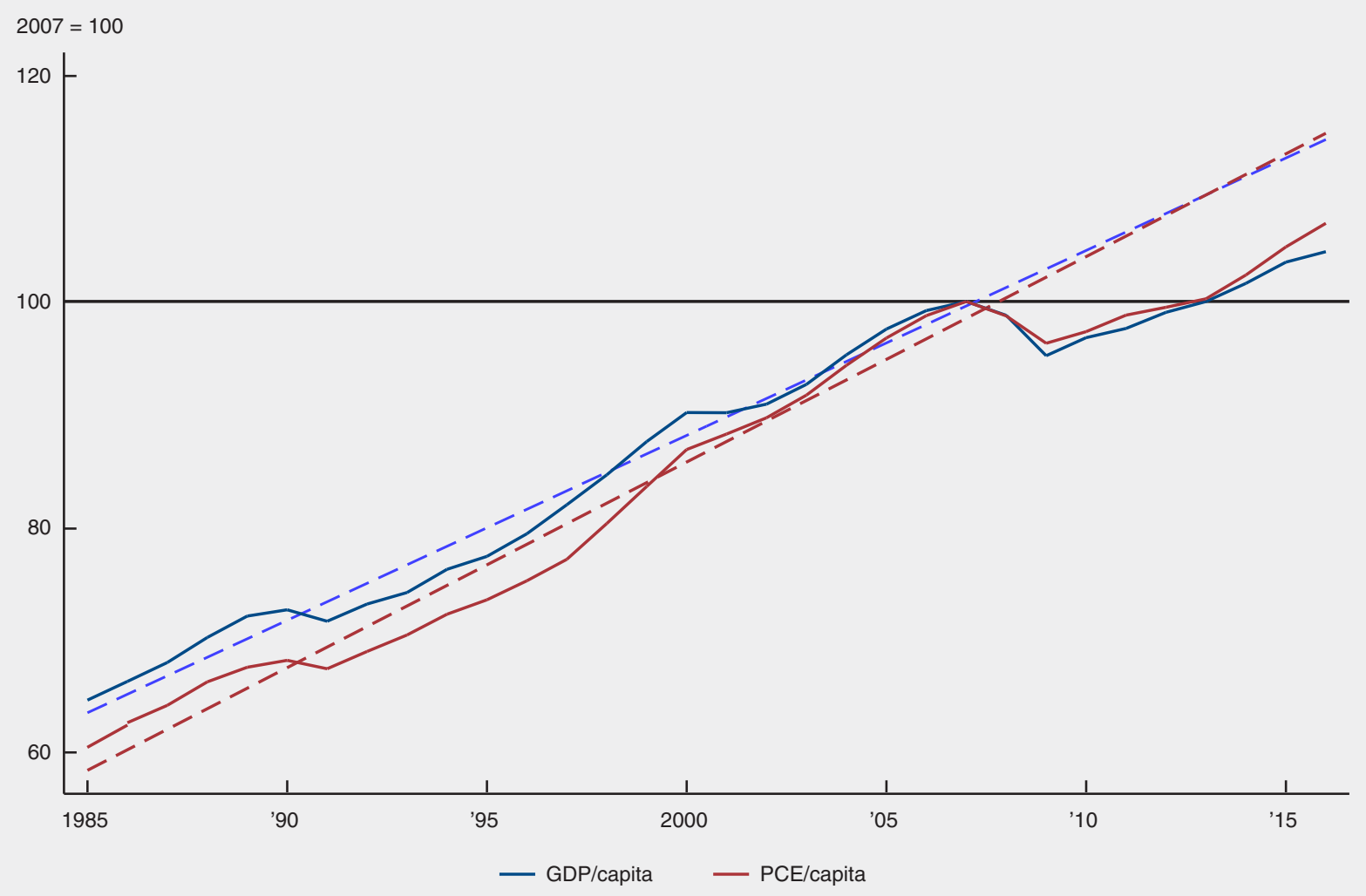

Notes: GDP indicates gross domestic product; PCE indicates personal consumption expenditures. The values in 2007 are normalized to 100. Linear trends are plotted using data from 1985 to 2007.

Sources: U.S. Bureau of Economic Analysis, U.S. Census Bureau, and Haver Analytics.

First, they do not incorporate the large wealth losses (due to drops in house prices and stock market values) that occurred during the Great Recession and have depressed aggregate consumption due to a negative wealth effect. Second, they take the view that there is only one asset and that borrowing-constrained people are largely people with low amounts of this composite asset. However, the composition of a household's portfolio is important to determine the extent to which the household is borrowing constrained. For instance, in a model with liquid and illiquid assets that are subject to adjustment costs, people might have significant holdings of illiquid wealth and still be borrowing constrained (Kaplan and Violante, 2014). Thus, these models understate the fraction of households that are borrowing constrained and, hence, the size of the associated consumption drop. Third, these models assume that financial frictions are constant, including during a large downturn. In contrast, credit standards tightened considerably during the Great Recession, which also tends to reduce consumption (Guerrieri and Lorenzoni, 2017). Fourth, these models assume that only unemployment risk changes over the cycle, while there is significant evidence that earnings risk conditional on being employed is asymmetric: Large earnings drops are much more likely than large earnings increases, and this asymmetry becomes more pronounced during recessions (Guvenen, Ozkan, and Song, 2014). If a household perceives higher earnings risk during a recession, it would likely cut consumption and increase savings, thus generating an even larger drop in aggregate consumption.

Thus, all four of these factors likely increase the size of the consumption drop that is related to household inequality, because they increase the fraction of borrowing-constrained households that have high marginal propensities to consume and whose consumption reacts more strongly to a negative aggregate shock. 
Interestingly, these factors do not apply symmetrically to all households. For instance, the wealth drop is more important for households in the top half of the wealth distribution, while credit market access plays a larger role for low-wealth households who lack alternative means of smoothing consumption. Accounting for these factors can thus improve the ability of the current models to match cross-sectional patterns of consumption responses.

One important implication of the four features that are missing in these macro benchmark models is that we should think more carefully how to best measure the fraction of households that are borrowing constrained and how this fraction changes over time and the business cycle. It is important to stress that the fraction of households that are borrowing constrained is not just the fraction of low-wealth households, but also depends on their portfolio composition, exposure to earnings risk, and, potentially, on what nondiscretionary expenses they expect (Campbell and Hercowitz, 2018). We thus need a better measure of borrowing-constrained households.

To help shed light on these important issues, we use the Panel Study of Income Dynamics (PSID) and credit bureau panel data (Equifax) to examine the interaction between consumption, wealth inequality, and borrowing constraints during the Great Recession. We find that, consistent with the models' implications, the poor and borrowing-constrained households have a larger consumption expenditure rate as a fraction of their income and that their expenditure rate dropped by more during the Great Recession. We then use various measures of borrowing constraints to get a sense of how the fraction of constrained households has changed over time. We document that, for all of the measures that we consider, the fraction of households that are borrowing constrained has drastically increased since the onset of the Great Recession and remained high, or even increased, all the way to 2012, the last year for which we currently have PSID data. Thus, it is not surprising that aggregate consumption has experienced such a large drop and remained depressed for a long time. Before we turn to our data analysis, we discuss what we know from macroeconomic theory in more detail.

\section{Krusell and Smith (1998)}

In Krusell and Smith's (KS) model, the consumers are infinitely lived, provide labor inelastically, and optimally choose how much to save and consume. They are ex-ante identical but get hit by an unemployment shock. Markets are incomplete: There is only one asset, aggregate capital, and consumers cannot borrow. The model induces endogenous wealth inequality: Although households face the same stochastic process for an endowment shock, they receive different sequences of the unemployment shock and are thus ex-post heterogeneous in their wealth holdings.

There is an aggregate shock that affects total factor productivity of both capital and labor (TFP) in the aggregate production function and the aggregate unemployment rate. A recession in this framework is thus characterized by lower aggregate wages and higher unemployment. The equilibrium interest rate is the marginal product of capital. The equilibrium wage is the marginal product of labor. Due to the aggregate shocks, both the interest rate and the wage fluctuate over time. Thus, because of aggregate uncertainty, consumers have to forecast future prices (both the wage and the interest rate). In principle, the whole distribution of wealth, together with the aggregate shock, is a state variable to forecast future prices.

We learn two main lessons from this paper. The first one is that today's average capital, or net worth, is enough to forecast future prices for a given aggregate shock, and that we therefore need to keep track of only one moment of the wealth distribution. The second main lesson from this paper is that the first result can still imply that the response of the aggregate time series depends on the distribution of wealth and the fraction of people that are constrained. In fact, the second moments of the aggregate time series in models 
FIGURE 2

\section{Policy functions and wealth distributions}

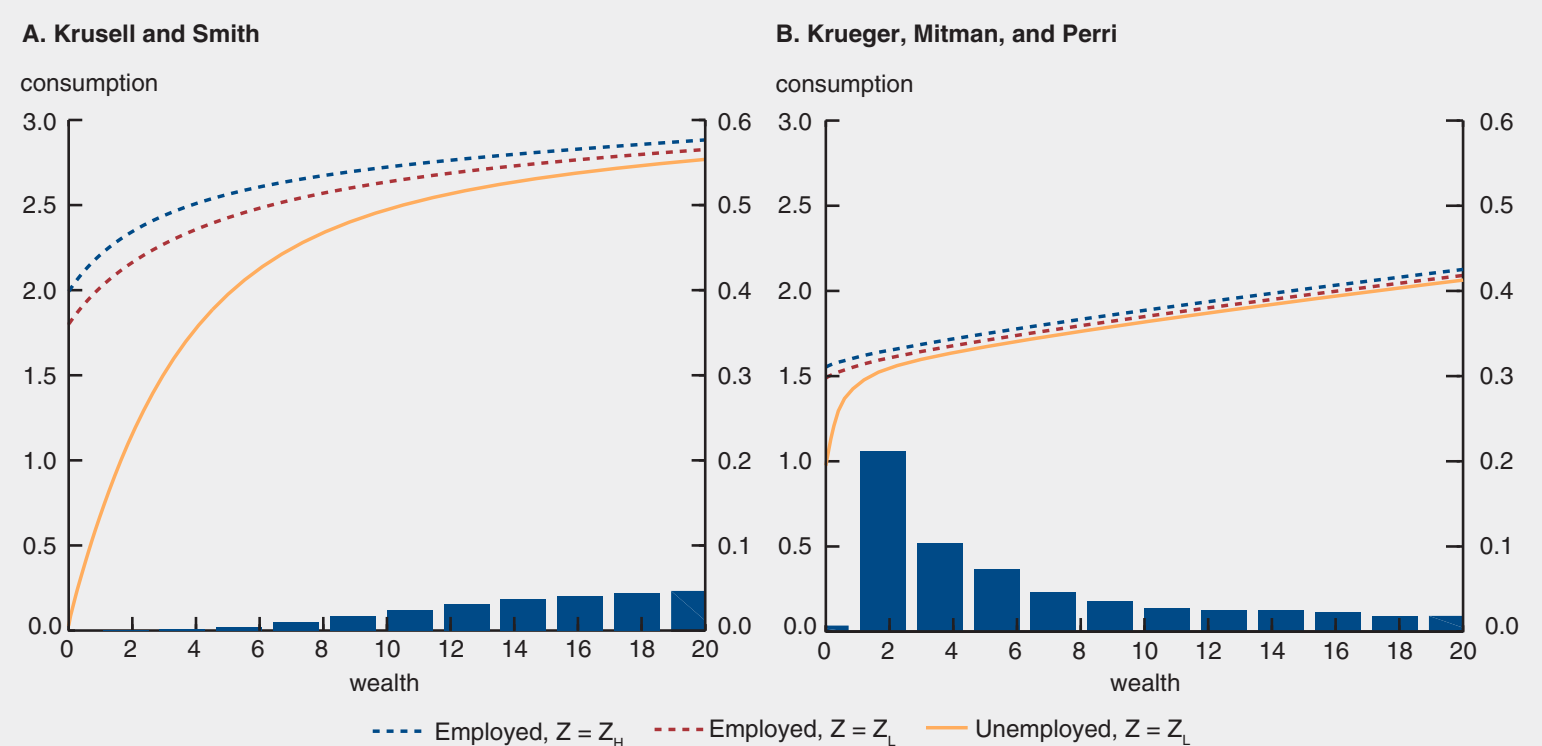

Source: Krueger, Mitman, and Perri, 2016.

with incomplete markets are different from those with a representative agent. Especially in models with more realistic wealth inequality, there is a larger correlation between consumption and income.

The key insight in these models with incomplete markets is that different saving (and consumption) propensities are associated with low levels of wealth. As wealth increases, the marginal propensity to save converges to one (permanent income behavior) and thus aggregates up across agents. Because the agents with lowest and most heterogeneous propensity to save (and highest propensity to consume) are associated with low wealth levels, they have very little effect on aggregate capital and prices, as opposed to the high-wealth agents whose policy functions aggregate. In contrast, because the poor have a high marginal propensity to consume, they account for a significant amount of aggregate consumption. Moreover, because they have little wealth to insulate their consumption from aggregate shocks affecting wages and income, they also have the largest consumption fluctuations over the cycle.

\section{Krueger, Mitman, and Perri (2016)}

Krueger, Mitman, and Perri (KMP) extend the KS framework with preference heterogeneity to include a stylized life-cycle structure with constant probabilities of aging or dying in each subperiod (working period and retirement), labor productivity shocks conditional on employment, and unemployment insurance.

Their key finding is that, in these economies, the decline in aggregate consumption in response to an aggregate shock is larger in an economy populated by more wealth-poor households because their consumption responds more strongly to aggregate shocks, which are characterized by a reduction in TFP and increased unemployment risk.

Figure 2 displays the consumption functions (plotted against individual wealth on the x-axis) and the pre-recession wealth distributions for the original KS economy (left-hand side) and the KMP economy (both graphs are from KMP). The lines represent the consumption functions of the employed in an expansion, the employed 
FIGURE 3

Consumption recessions in various versions of the model

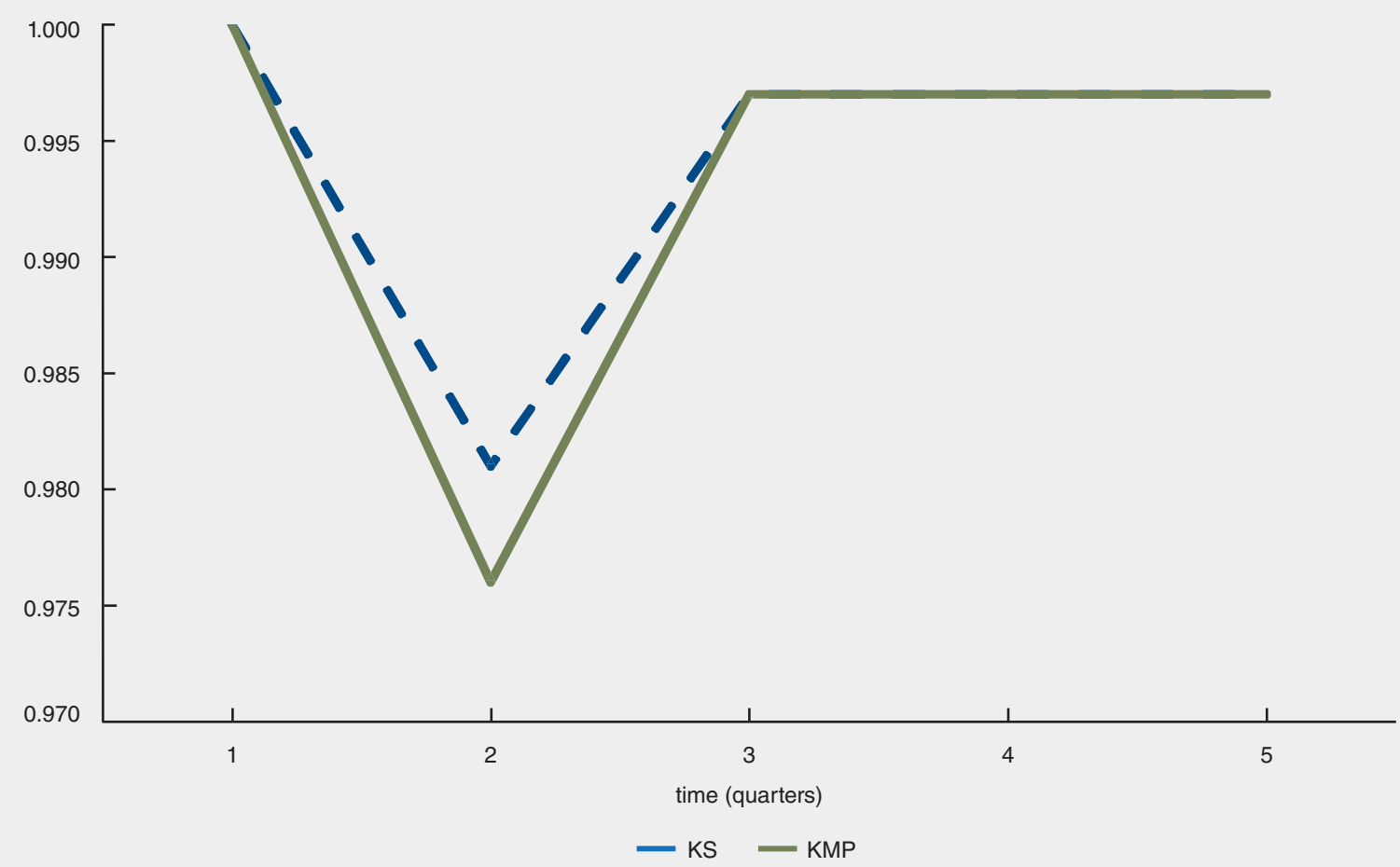

Note: Lines represent impulse response functions to a recession in the KS and KMP models. Source: Krueger, Mitman, and Perri, 2016.

in a recession, and the unemployed in a recession. Thus, for a given wealth level, the vertical difference between the consumption functions for the employed in the good aggregate state and the employed in the bad aggregate state gives the consumption drop in a large recession, conditional on the aggregate state switching but on not losing a job. In the same way, the vertical difference between the consumption function of the employed in an expansion and the consumption function of the unemployed in a recession shows the consumption drop for a household that experiences a recession and unemployment at the same time.

The figure reveals several interesting features. First, for a given level of wealth, the drop in consumption is larger in the original KS economy and especially so for households with little to no assets. Second, while there are almost no people in this situation in the original KS economy, there are many more households in those wealth quantiles in the KMP economy. It should be noted that average wealth is the same in the two economies. As it turns out, the KMP economy displays a larger consumption drop than the KS economy precisely because there are more people with low wealth holdings. Figure 3 (also from KMP) highlights this result.

\section{Results from the models, a discussion leading to our data analysis}

These two papers stress the importance of modeling heterogeneity and constrained households in understanding aggregate consumption and output dynamics. However, these models abstract from features of the Great Recession that are likely important in helping us to understand the behavior of aggregate consumption during and after that recession. For example, while the additional heterogeneity in KMP deepens the initial consumption drop, it recovers at the same rate as the KS model. The richer dimensions of heterogeneity we document could potentially help future models match both the steep initial decline and the slow recovery in consumption we observed in the Great Recession. 
The features we consider include, first, changes in the value of wealth holdings (and thus the fraction of poor households) due to drops in house prices and financial asset valuation. Second, we study the implications of the observation that the asset structure is much richer than just one asset. A household's portfolio allocation and its liquidity can have crucial implications for who is constrained (the wealthy-hand-to-mouth). Third, changes in credit constraints that occurred, due to changes in credit conditions during the downturn, are likely important. Fourth, we examine changes in earnings risk for the employed in recessions and expansions. We know that the distribution of earnings displays more negative skewness in recessions, for instance. It is also possible that the persistence of earnings might depend on the status of the aggregate economy and one's earning level.

We now turn to discussing key aspects of the data and the strengths and weaknesses of the models in explaining empirical consumption dynamics after large shocks.

\section{Data}

\section{Panel Study of Income Dynamics}

We utilize the Panel Study of Income Dynamics (PSID) to analyze the relationship between household inequality and consumption dynamics. The PSID has two important advantages from the standpoint of the questions that we are asking. First, it provides information on earnings, income, consumption, and wealth for a sample that is representative of the U.S. population. Second, it has a panel dimension that allows us to track households over time in addition to performing cross-sectional investigations. Thus, we can examine how wealth and consumption have changed for the same households.

We use data from the 2001 to 2013 PSID waves (covering the years 2000 to 2012), with particular focus on 2004, 2006, and 2010. Our baseline sample in these years consists of families with household heads aged 25 to 60 . We exclude a few households whose total annual consumption is implausibly small, less than $\$ 1,000$ in 2006 dollars. Our wealth quintiles are defined over this working-age sample. When analyzing changes over time, we make these restrictions only in the base year. Much of our analysis focuses on three variables: total income, consumption expenditures, and net worth. All dollar values are deflated to 2006 using the Consumer Price Index, unless stated otherwise.

Total income includes all pre-tax sources of household income from all family members, including Social Security income and other transfers, as well as a family's income from assets and businesses. Transfer income includes unemployment compensation, transfers from other family members, and welfare benefits, among others. Total income also includes retirement and pension income. Net worth is composed of net housing equity, net value of other real estate, net value of farm or business, net value of vehicles, value of annuities and retirement accounts, value of nonretirement investments and savings, and the net value of other assets less the value of other liabilities. After 2010, the value of other liabilities is subdivided into credit card debt, student loans, medical bills, legal bills, and other family loan debt. In the analysis that considers illiquid housing wealth, we only look at the net equity in the primary home and other real estate. Net worth does not include the present value of defined-benefit pension income.

While the PSID harmonizes the variables for total family income and net worth, we must construct consumption expenditures using disparate expenditure categories. These are: expenditures on transportation, vehicles purchased in the current year, food, clothing, education, child care, entertainment, recreation, vacation, utilities, rent, imputed rents for homeowners, property taxes, household repairs, household durables, homeowners' insurance, out-of-pocket medical care, and health insurance premiums. As in KMP, we impute the rental value for homeowners by multiplying the total value of a household's home by an interest rate of 4 percent. 
This definition of consumption is only available for 2004 onward as expenditures on clothing, entertainment, recreation, vacation, household durables, and household repairs were not collected prior to this. We adjust all expenditure variables to an annual frequency. ${ }^{2}$

\section{Equifax}

We also make use of the Equifax-FRBNY Consumer Credit Panel (CCP), which is a longitudinal data set containing quarterly credit bureau records for a nationally representative 5 percent random sample of individual borrowers. The CCP database also includes records of all household members of the primary sample borrower. These data include information on all aspects of individual- and household-level credit and debt, which includes credit cards, auto loans, and student debt, as well as first- and second-lien mortgages. The data also include individual credit scores and the number of credit applications, which allow us to track household creditworthiness and demand for credit over time. ${ }^{3}$

\section{Important dimensions of heterogeneity in the PSID}

We begin by discussing several key empirical facts from the PSID. ${ }^{4}$ Table 1 reports the marginal distributions of earnings, income, consumption expenditures, and net worth in 2006, on the eve of the recession. All of these measures of household well-being are very unevenly distributed, but some more so than others.

For the moment, we will take net worth as a measure of household constraints, since less wealthy households are likely less able to respond to shocks. How much do wealth-poor households contribute to aggregate consumption? To answer this question, table 2 reports the distribution of several variables, conditional on wealth quintile in 2006. It reveals that asset-poor households make up a sizable measure of aggregate consumption expenditures. In fact, the bottom two wealth quintiles account for 30 percent of expenditures in 2006. Not surprisingly, households in these quintiles spend much higher shares of their total income on consumption (expenditure rates).

Table 3 shows that the low-wealth quintiles are populated by households that are younger, less educated, have low propensities to own homes or financial assets, and are less likely to hold full-time employment

\begin{tabular}{|lcccc|}
\hline \multicolumn{5}{c|}{ TABLE 1 } \\
\multicolumn{5}{c}{ Means and marginal distributions in 2006 } \\
\hline Labor earnings & Total income & $\begin{array}{c}\text { Consumption } \\
\text { expenditures }\end{array}$ & Net worth \\
\hline Mean (2006) & 66,425 & 80,277 & 47,526 & 324,973 \\
\hline Q1 & 2.1 & 4.4 & 6.1 & -1.5 \\
Q2 & 9.8 & 10.9 & 12.2 & 1.2 \\
Q3 & 16.2 & 16.3 & 17.2 & 6.0 \\
Q4 & 24.9 & 23.4 & 23.4 & 14.7 \\
Q5 & 47.1 & 45.0 & 41.0 & 79.6 \\
\hline 90-95\% & 9.1 & 9.0 & 9.0 & 11.0 \\
95-99\% & 13.8 & 13.6 & 11.3 & 23.4 \\
Top 1\% & 7.2 & 7.1 & 5.8 & 26.3 \\
\hline Gini & 0.45 & 0.46 & 0.39 & 0.76 \\
\hline Sample size & 6,231 & 6,231 & 6,231 & 6,231 \\
Source: University of Michigan, Institute for Social Research, Panel Study of Income Dynamics. & \\
\hline
\end{tabular}




\section{TABLE 2}

Shares and means by net worth quintile in 2006

\begin{tabular}{|c|c|c|c|c|c|c|c|c|c|}
\hline & \multicolumn{4}{|c|}{$\%$ Share of aggregate } & \multicolumn{4}{|c|}{ Mean (000s \$ 2006) } & \multirow[b]{2}{*}{$\begin{array}{c}\text { Expenditure } \\
\text { rate }(\%)\end{array}$} \\
\hline & $\begin{array}{c}\text { Net } \\
\text { worth }\end{array}$ & $\begin{array}{l}\text { Labor } \\
\text { earnings }\end{array}$ & $\begin{array}{c}\text { Total } \\
\text { income }\end{array}$ & $\begin{array}{c}\text { Cons. } \\
\text { exp. }\end{array}$ & $\begin{array}{c}\text { Net } \\
\text { worth }\end{array}$ & $\begin{array}{l}\text { Labor } \\
\text { earnings }\end{array}$ & $\begin{array}{c}\text { Total } \\
\text { income }\end{array}$ & $\begin{array}{c}\text { Cons. } \\
\text { exp. }\end{array}$ & \\
\hline Q1 & -1.5 & 11.6 & 11.5 & 14.6 & -15.5 & 29.4 & 35.0 & 26.8 & 76.8 \\
\hline Q2 & 1.2 & 14.2 & 14.0 & 15.3 & 13.3 & 37.8 & 44.9 & 29.6 & 66.0 \\
\hline Q3 & 6.0 & 20.3 & 19.5 & 19.6 & 71.1 & 57.4 & 66.5 & 40.2 & 60.5 \\
\hline Q4 & 14.7 & 20.8 & 20.6 & 20.9 & 213.2 & 73.1 & 86.8 & 53.2 & 61.2 \\
\hline Q5 & 79.6 & 33.1 & 34.4 & 29.7 & $1,344.4$ & 134.6 & 168.4 & 87.8 & 52.2 \\
\hline
\end{tabular}

Correlation

with net worth

$0.31 \quad 0.38 \quad 0.21$

Source: University of Michigan, Institute for Social Research, Panel Study of Income Dynamics.

\begin{tabular}{|c|c|c|c|c|c|c|c|}
\hline \multicolumn{8}{|c|}{ TABLE 3} \\
\hline \multicolumn{8}{|c|}{ Household characteristics by net worth quintile in 2006} \\
\hline & Age & $\begin{array}{c}\text { Years of } \\
\text { education }\end{array}$ & $\begin{array}{l}\text { Worked } \\
\text { last year }\end{array}$ & $\begin{array}{l}\text { Hours if } \\
\text { worked }\end{array}$ & $\begin{array}{l}\text { Unemployed } \\
\text { last year }\end{array}$ & Own home & $\begin{array}{c}\text { Own } \\
\text { financial } \\
\text { assets }\end{array}$ \\
\hline Q1 & 39.2 & 12.7 & 83.4 & 1,906.2 & 17.3 & 12.7 & 9.9 \\
\hline Q2 & 40.3 & 12.5 & 89.0 & $2,107.1$ & 10.7 & 36.4 & 14.3 \\
\hline Q3 & 42.3 & 13.2 & 92.3 & $2,219.8$ & 5.5 & 80.2 & 33.6 \\
\hline Q4 & 46.2 & 13.5 & 95.0 & $2,222.4$ & 3.1 & 87.7 & 54.9 \\
\hline Q5 & 48.8 & 14.8 & 94.7 & $2,316.1$ & 3.3 & 93.6 & 82.7 \\
\hline
\end{tabular}

throughout the year, as evidenced both by the number of hours worked and prevalence of unemployment spells. The data in these tables corroborate the essential ingredients of KMP: 1) a large fraction of households have no assets but account for a significant part of aggregate consumption; and 2) these households are vulnerable to shocks, as their low asset positions are compounded by lower levels of human capital, whether acquired through schooling or work experience.

How did these household groups respond to the Great Recession? Table 4 reports annualized nominal changes in select variables before and during the Great Recession, conditional on initial wealth quintile. These changes are computed holding the initial quintile composition fixed. For instance, to compute the change in consumption expenditures for households in the bottom wealth quintile between 2004 and 2006, we take all households in that quintile in 2004 and compute their mean consumption expenditures in 2004 and 2006. The annualized change in these means is reported in the table. Changes in expenditure rates are constructed similarly but are reported as percentage point differences.

The top row of table 4 shows aggregate growth rates that tell a familiar tale of the Great Recession. ${ }^{5}$ After expanding at a pace of 14.1 percent during the boom years, aggregate net worth declined at an annual rate of 3.4 percent between 2006 and 2010. The growth rate of aggregate total income also slowed down from 2.6 percent to only 0.8 percent per year. However, the slowdown in aggregate consumption proved to be much faster: After increasing at an average rate of 5.5 percent per year, consumption fell at an average 


\section{TABLE 4}

Annualized nominal changes in financial variables over 2004, 2006 net worth quintiles

\begin{tabular}{|c|c|c|c|c|c|c|c|c|c|c|c|c|}
\hline & \multicolumn{3}{|c|}{ Net worth (\%) } & \multicolumn{3}{|c|}{ Total income (\%) } & \multicolumn{3}{|c|}{$\begin{array}{l}\text { Consumption } \\
\text { expenditures (\%) }\end{array}$} & \multicolumn{3}{|c|}{$\begin{array}{c}\text { Expenditure rate } \\
\text { (percentage points) }\end{array}$} \\
\hline & 04-06 & $06-10$ & $\Delta$ & 04-06 & 06-10 & $\Delta$ & 04-06 & 06-10 & $\Delta$ & 04-06 & 06-10 & $\Delta$ \\
\hline All & 14.1 & -3.4 & -17.6 & 2.6 & 0.8 & -1.8 & 5.5 & -0.8 & -6.4 & 1.6 & -0.9 & -2.5 \\
\hline Q1 & & & & 6.0 & 5.4 & -0.6 & 6.4 & 0.8 & -5.5 & 0.2 & -3.1 & -3.3 \\
\hline Q2 & 69.1 & 16.1 & -53.0 & 4.5 & 2.5 & -2.0 & 5.9 & 1.8 & -4.2 & 0.9 & -0.4 & -1.3 \\
\hline Q3 & 26.9 & 3.9 & -22.9 & 4.9 & 1.6 & -3.3 & 9.0 & 0.4 & -8.6 & 2.3 & -0.7 & -3.0 \\
\hline Q4 & 15.4 & 1.1 & -14.3 & 4.6 & 1.7 & -2.9 & 6.0 & -1.2 & -7.2 & 0.8 & -1.7 & -2.5 \\
\hline Q5 & 11.0 & -5.6 & -16.6 & -0.4 & -1.9 & -1.4 & 3.2 & -2.9 & -6.1 & 1.7 & -0.6 & -2.3 \\
\hline
\end{tabular}

Notes: Changes in expenditure rates are expressed as percentage point changes. Changes in net worth, income, and consumption expenditures are expressed as percentage changes.

Source: University of Michigan, Institute for Social Research, Panel Study of Income Dynamics.

rate of 0.8 percent between 2006 and 2010. These relative movements in growth rates of income and consumption are reflected in absolute declines in the aggregate expenditure rate.

A convenient metric for measuring the effect of the Great Recession is the change in nominal growth rates between the 2004-06 and 2006-10 periods. The Great Recession depressed total income growth for all wealth groups but in a non-monotonic fashion. Households in the middle of the wealth distribution (quintiles 3 and 4) experienced the greatest slowdown, while for those at the lowest quintile total income growth decelerated much less ( -0.6 percent per year). Consumption growth rates also decreased for all wealth groups, with the slowdown again being most severe in the middle of the wealth distribution.

Low-wealth households experienced a slowdown in consumption growth that was barely above those in the highest-wealth quintile and well below those in quintiles 3 and 4. This finding is consistent with results in Meyer and Sullivan (2013), which documents a decline in consumption inequality during the Great Recession. They show that the fall in asset prices (both housing and financial) had a disproportionate effect on households with higher ex-ante consumption levels.

Importantly, slowdowns in consumption growth were larger than drops in income growth for all wealth groups. As a result, the share of income spent on consumption (expenditure share) declined for all wealth groups, but the poorest households experienced the largest decline. This empirical fact is consistent with the main intuition of the KMP model: When unemployment risk rises, low-wealth households cut back consumption because they fail to accumulate wealth that can be used to smooth consumption fluctuations. This happens whether they actually become unemployed or not. In the latter case, they cut consumption to build up their precautionary savings given the heightened unemployment risk during a recession.

\section{Matching heterogeneous patterns in the data}

As shown in figure 3, the KMP model delivers a larger response to an aggregate recession shock than a model with a smaller wealth dispersion. It thus matches important aspects of the data and shows that an economy with borrowing-constrained agents can generate larger drops in aggregate consumption. As shown in table 5, the KMP model does well in matching heterogeneity in declines in disposable income, which drops less in recessions for low-wealth households (Q1-Q2) than high-wealth households in both the model and the data. The model also captures the qualitative ordering of recession-driven changes in expenditure rates. In particular, the drops in expenditures of the two lowest-wealth quintiles are smaller than the drops in expenditures of the highest-wealth quintiles. 
TABLE 5

Difference in annualized growth rates between recession period and normal times

\begin{tabular}{|c|c|c|c|c|c|c|c|c|}
\hline & \multicolumn{2}{|c|}{ Net worth (\%) } & \multicolumn{2}{|c|}{$\begin{array}{l}\text { Disposable } \\
\text { income (\%) }\end{array}$} & \multicolumn{2}{|c|}{$\begin{array}{c}\text { Consumption } \\
\text { expenditures (\%) }\end{array}$} & \multicolumn{2}{|c|}{$\begin{array}{c}\text { Expenditure rate } \\
\text { (percentage points) }\end{array}$} \\
\hline & Data & Model & Data $^{a}$ & Model & Data & Model & Data & Model \\
\hline Q1 & & -20 & -0.7 & -2.3 & -5.5 & -2.2 & -3.3 & 0.0 \\
\hline Q2 & -53 & -18 & -2.6 & -2.8 & -4.2 & -2.4 & -1.3 & 0.3 \\
\hline Q3 & -23 & -12 & -3.3 & -4.0 & -8.6 & -2.7 & -3.0 & 1.4 \\
\hline Q4 & -14 & -5 & -3.3 & -4.5 & -7.2 & -2.8 & -2.5 & 2.0 \\
\hline Q5 & -17 & -4 & -3.0 & -5.4 & -6.1 & -2.9 & -2.3 & 3.2 \\
\hline All & -17.6 & -4 & -2.9 & -4.4 & -6.4 & -2.6 & -2.5 & 1.3 \\
\hline
\end{tabular}

${ }^{a}$ Krueger, Mitman, and Perri calculate disposable, post-tax income and use this in their model. Since our analysis uses only pre-tax income, we report both their data and model results for this field. All other data results report our own computations. Source: University of Michigan, Institute for Social Research, Panel Study of Income Dynamics; and Krueger, Mitman, and Perri (2016) model results.

However, the Great Recession was associated with large wealth losses, tightening of borrowing constraints, and increased earnings uncertainty. These forces would take the model even closer to the data. They could further reduce aggregate consumption growth and amplify the consumption response relative to income drops. They could also further contribute to a slow recovery in consumption. Because wealth losses fall unevenly across the distribution, the implied reductions in consumption growth rates would be heterogeneous.

\section{Additional elements of the Great Recession}

\section{Shocks to wealth}

Unlike the baseline model, the Great Recession was characterized by substantial declines in household wealth. Figure 4 demonstrates the leftward shift in distribution of household wealth between the 2006 and 2010 PSID surveys. The share of households with negative net worth jumped from 16 percent to 24 percent, and mean household net worth plummeted from $\$ 324,973$ to $\$ 197,780$ in 2006 dollars. In the context of the KMP model, this drop in household net worth could reinforce the negative consumption dynamics by altering the wealth distribution in figure 2. Put differently, a recession that brings about a sizable leftward shift in the wealth distribution elicits an additional consumption response, especially among households who bear the brunt of this shock.

We can get some additional insight into these consumption dynamics by exploiting the panel structure of the PSID and linking changes in wealth with changes in consumption at the household level. Table 6 presents the shift in the distribution of household wealth between 2006 and 2010 as transitions across fixed net worth quintiles, defined by their 2006 threshold values. Each row of the table shows the distribution of households in a given wealth quintile in 2006 across wealth groupings in 2010. For example, 43.8 percent of households in the middle quintile of the 2006 net worth distribution remained in the same group by 2010 . However, more than one-third of households in this quintile $(12.5 \%+22.9 \%)$ had lost enough wealth by 2010 to drop into the bottom two quintiles. For example, 12.5 percent of households in the middle 20 percent of net worth in 2006 dropped to the bottom 20 percent in 2010. This group had an average nominal net worth of $\$ 73,900$ in 2006 and dropped to a 2010 mean of $-\$ 33,100$. Similarly, for those who transitioned from the third to the second quintile, 22.9 percent of households dropped from an average wealth level of $\$ 73,000$ to an average of $\$ 20,800$. 
FIGURE 4

Cross-sectional distributions of net worth in 2006 and 2010

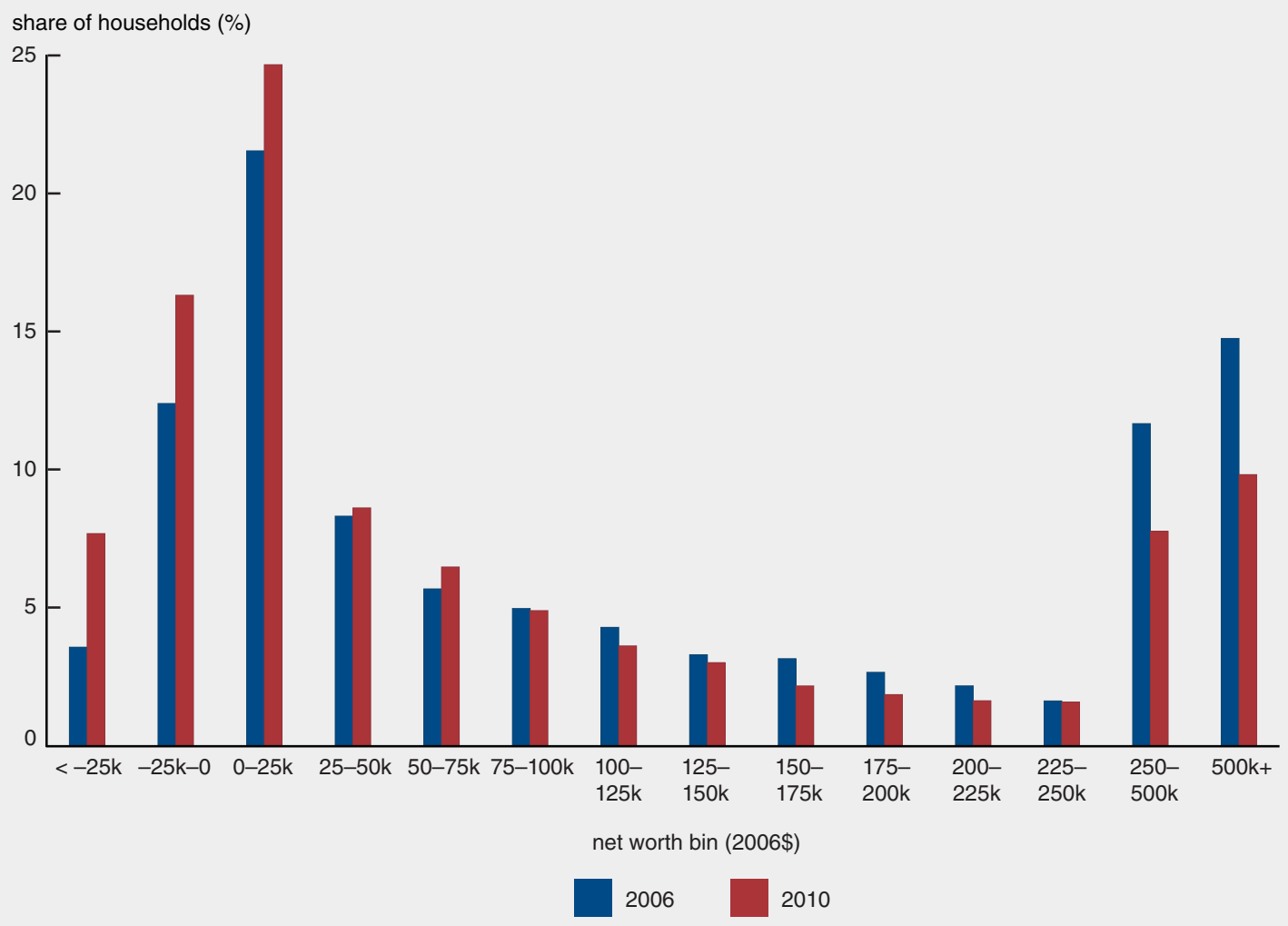

Source: University of Michigan, Institute for Social Research, Panel Study of Income Dynamics.

\section{TABLE 6}

Transitions and annualized nominal consumption changes (\%) across 2006 net worth quintiles, 2006-10

\begin{tabular}{|c|c|c|c|c|c|c|c|}
\hline \multirow[b]{2}{*}{ Limits } & \multirow[b]{2}{*}{$2006 Q$} & \multicolumn{5}{|c|}{2010} & \multirow[b]{2}{*}{ Total } \\
\hline & & Q1 & Q2 & Q3 & Q4 & Q5 & \\
\hline \multirow[t]{2}{*}{$\leq \$ 2.5 \mathrm{k}$} & Q1 & 64.6 & 24.6 & 8.1 & 2.1 & 0.5 & \\
\hline & & {$[-0.5]$} & [2.5] & [3.9] & [5.5] & [4.6] & [0.9] \\
\hline \multirow[t]{2}{*}{$\$ 2.5-37.4 \mathrm{k}$} & Q2 & 30.2 & 46.2 & 18.3 & 4.6 & 0.7 & \\
\hline & & [1.1] & [1.3] & [2.0] & [9.0] & [5.4] & {$[1.8]$} \\
\hline \multirow[t]{2}{*}{$\$ 37.4-133 k$} & Q3 & 12.5 & 22.9 & 43.8 & 16.9 & 4.0 & \\
\hline & & {$[-2.8]$} & {$[-3.3]$} & {$[0.9]$} & [5.1] & [3.1] & [0.4] \\
\hline \multirow[t]{2}{*}{$\$ 133-371 \mathrm{k}$} & Q4 & 7.6 & 8.2 & 26.6 & 42.9 & 14.7 & \\
\hline & & {$[-2.9]$} & {$[-4.8]$} & {$[-3.7]$} & {$[-0.1]$} & [1.9] & {$[-1.2]$} \\
\hline \multirow[t]{4}{*}{$>\$ 371 \mathrm{k}$} & Q5 & 3.3 & 1.4 & 7.2 & 20.0 & 68.2 & \\
\hline & & {$[-26.8]$} & {$[-12.2]$} & {$[-5.9]$} & {$[-1.2]$} & {$[-1.3]$} & {$[-2.9]$} \\
\hline & Total & 23.7 & 20.6 & 20.8 & 17.3 & 17.6 & \\
\hline & & {$[-3.3]$} & {$[-0.6]$} & {$[-0.8]$} & [1.0] & {$[-0.7]$} & \\
\hline
\end{tabular}

Source: University of Michigan, Institute for Social Research, Panel Study of Income Dynamics. 
The table also captures the consumption growth rates for each of these groups, located in the brackets below the transition probabilities. Looking at households that moved from the middle quintile in 2006 to the bottom quintiles in 2010 shows that the deterioration in their wealth position was accompanied by massive reductions in consumption of about 3 percent per year. Table 6 shows that, in general, downward movements in wealth (the lower diagonal part of the transition matrix) are associated with negative consumption growth rates, shown in bold. The total row of the table again underscores the shift in the wealth distribution: the bottom quintile in $2006(<\$ 2,500$ in net worth) by construction accounted for 20 percent of households, but 23.7 percent of households found themselves with less than $\$ 2,500$ in net worth in 2010.

\section{Shocks to composition of wealth}

Housing equity represents the single-largest wealth component for the majority of households, although it is illiquid. During the run-up to the Great Recession, financial innovations made it much easier for households to use housing equity to support consumption, either by extracting it directly or by borrowing against it (Bhutta and Keys, 2016). Case, Quigley, and Shiller (2013) estimate propensities to consume out of different types of wealth by analyzing changes in per capita consumption expenditures, income, financial wealth, and housing wealth in a quarterly panel of U.S. states spanning 1975 to 2012. They find much higher elasticities of consumption for housing than for financial wealth and attribute this result to changes in tax laws and the above-mentioned financial innovations. Thus, a drop in house values could further contribute to the drop in consumption.

In figure 5, we again exploit the panel structure of PSID to show the distribution of individual changes in real housing wealth between 2006 and 2010, expressed in annualized, real percentage terms. The smaller figures show the unconditional distribution in each 2006 wealth quintile, while the top figure shows the overall distribution, which is the sum of the smaller histograms. The overall distribution of housing wealth changes (top panel) was strongly asymmetric as many households experienced losses in real terms. On average, housing wealth declined by an average of 6.4 percent per year over this period, and as many as 17.8 percent of PSID homeowners lost all of their housing wealth, whether through foreclosure (the $-100 \%$ group) or by owing more than their house was worth (the "underwater" or $<-100 \%$ group). The rest of the panels show the unconditional distributions of changes for each of the 2006 wealth groups. In these panels, non-homeowners and those with little housing wealth in 2006 are omitted and thus the sum over all the bins in each panel will roughly equal the homeownership rate for that quintile.

Consequently, the histograms for the bottom two wealth quintiles suggest that housing losses there were limited because of low ownership rates. However, the rest of the wealth distribution was hit hard. In the middle quintile, complete loss of all housing equity represented the likeliest outcome. Although foreclosures were not nearly as common in the top wealth deciles, the share of households facing losses was even greater.

\section{Changes in credit accessibility}

Figure 5 describes the erosion in housing wealth, which is commonly used as collateral. However, in addition to experiencing negative wealth shocks, households were also faced with a more adverse credit environment with the onset of the Great Recession. Lenders tightened their credit standards for home mortgages and other credit products. Moreover, as delinquency rates rose across credit markets, household credit scores deteriorated, which further contributed to difficulties in accessing credit.

To get some sense of the magnitude of the shock to credit access, we turn to the Equifax panel data. Figure 6 shows the distribution of credit risk scores ${ }^{6}$ in a representative sample of households in 2006 and for the 
Distribution of household-level annualized, real percentage changes: Illiquid net worth

A. All households with housing wealth in 2006

share of households (>1k in 2006) (\%)

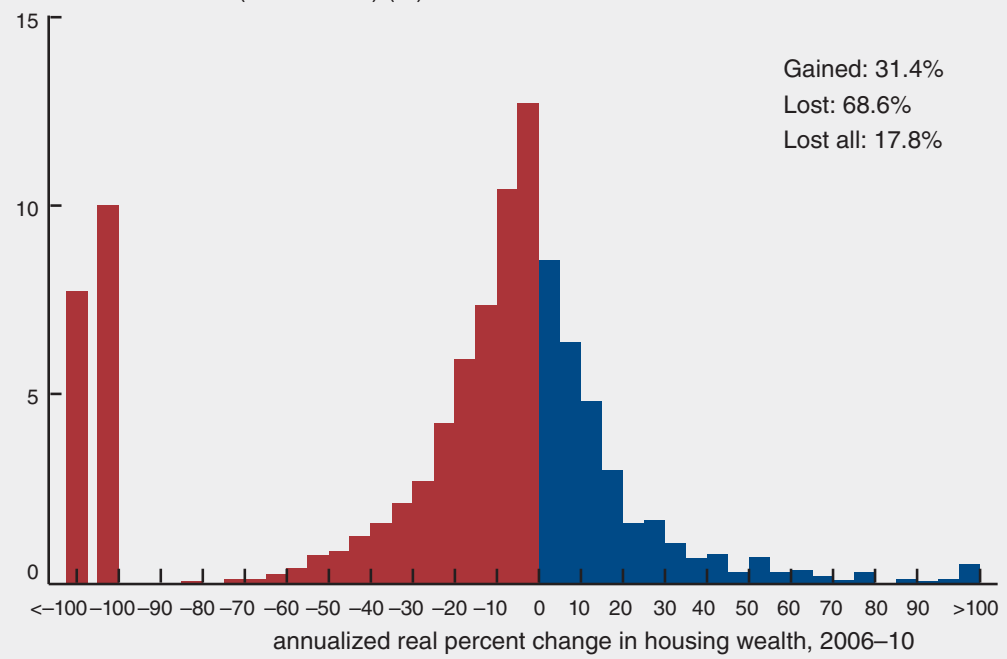

B. Q1

share of households (>1k in 2006) $(\%)$

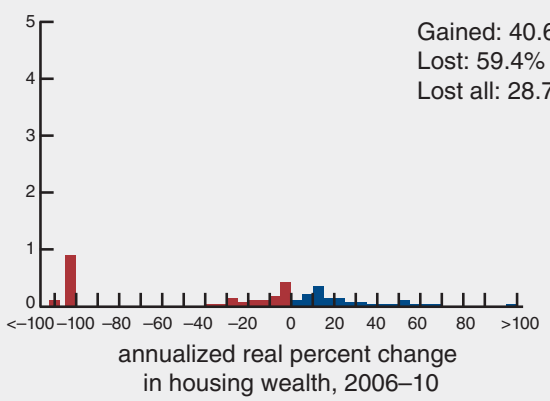

C. Q2

share of households (>1k in 2006) (\%)

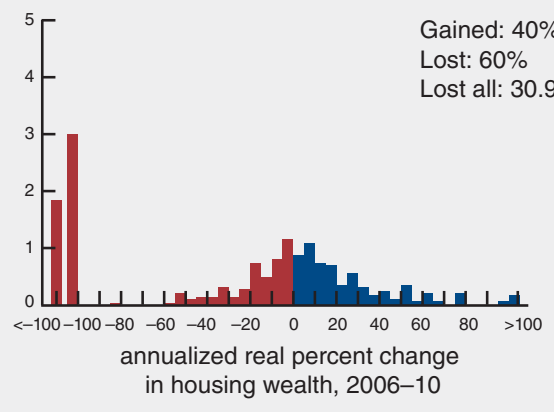

D. Q3

share of households (>1k in 2006) (\%)

${ }^{5}$ Gained: $36.1 \%$ Lost: $63.9 \%$

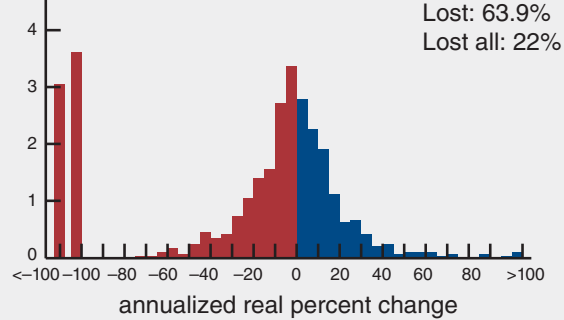

annualized real percent change

E. Q4

share of households (>1k in 2006) $(\%)$

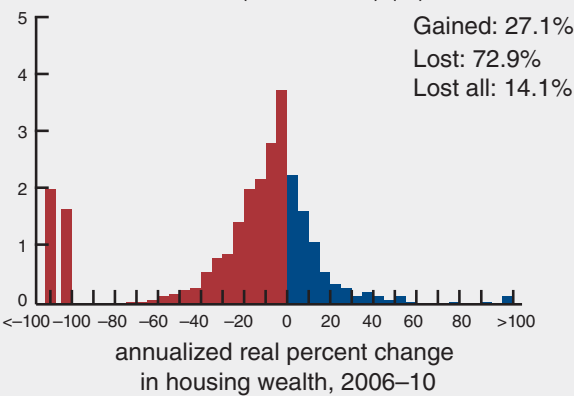

F. Q5

share of households (>1k in 2006) (\%)

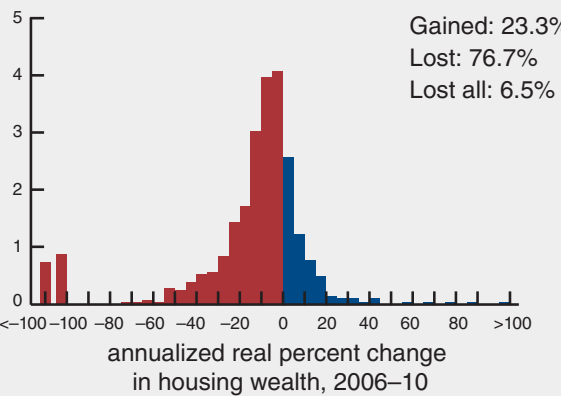

Source: University of Michigan, Institute for Social Research, Panel Study of Income Dynamics. 


\section{Changes in credit risk scores and credit cutoffs, 2006-10}

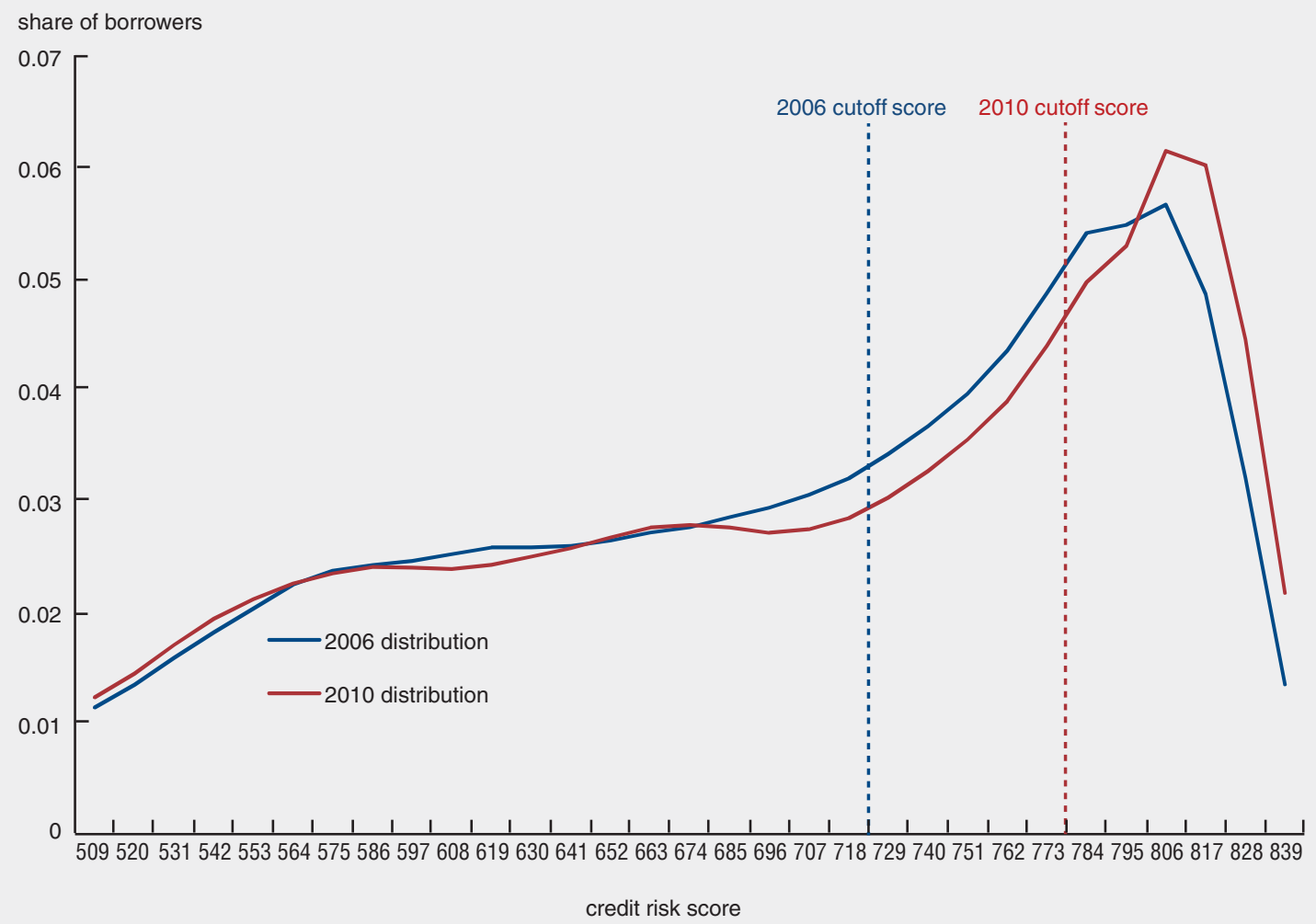

Source: Equifax Credit Panel.

same sample in 2010. Unlike household wealth, the distribution of credit scores did not shift uniformly to the left. Rather, by 2010, the credit score distribution became much thinner in the middle range of creditworthiness (690-790) and more concentrated at the very top. On net, the fraction of households that remained above the informal midpoint of the prime credit score range (credit score $=720$ ) was nearly unchanged.

Instead, it was the tightening of minimum credit standards, shown by the dashed vertical lines, that pushed a large fraction of households out of credit markets. As shown in figure 7, according to mortgage-servicing data from McDash Analytics, a credit score of 720 roughly corresponded to the median score of a borrower approved for a home mortgage by Fannie Mae or Freddie Mac prior to the Great Recession. Over this period, households with credit scores between 680 and 780 - the "prime" group in figure 8-experienced a success rate above 80 percent in getting their credit applications approved. Applying a credit score of 720 as a notional cutoff for ready credit access to the distribution in figure 6 places 47 percent of households in this category. However, by 2010, the same criteria for ready credit access - obtaining mortgage credit from the GSEs or having undiminished success rates for credit applications - required a credit score of about 780. This shift in credit requirements, shown by the red dashed line, shrank the fraction of households with easy credit access to just under 30 percent.

Evidence of credit tightening during the Great Recession can be seen in the mortgage-servicing data on median credit scores for newly originated mortgages depicted in figure 7. Stricter credit requirements are apparent both for mortgages backed by Fannie Mae and Freddie Mac and for mortgages for first-time homebuyers explicitly guaranteed by the U.S. government through the Federal Housing Agency (FHA) or 


\section{FIGURE 7}

\section{Median credit risk score at mortgage origination}

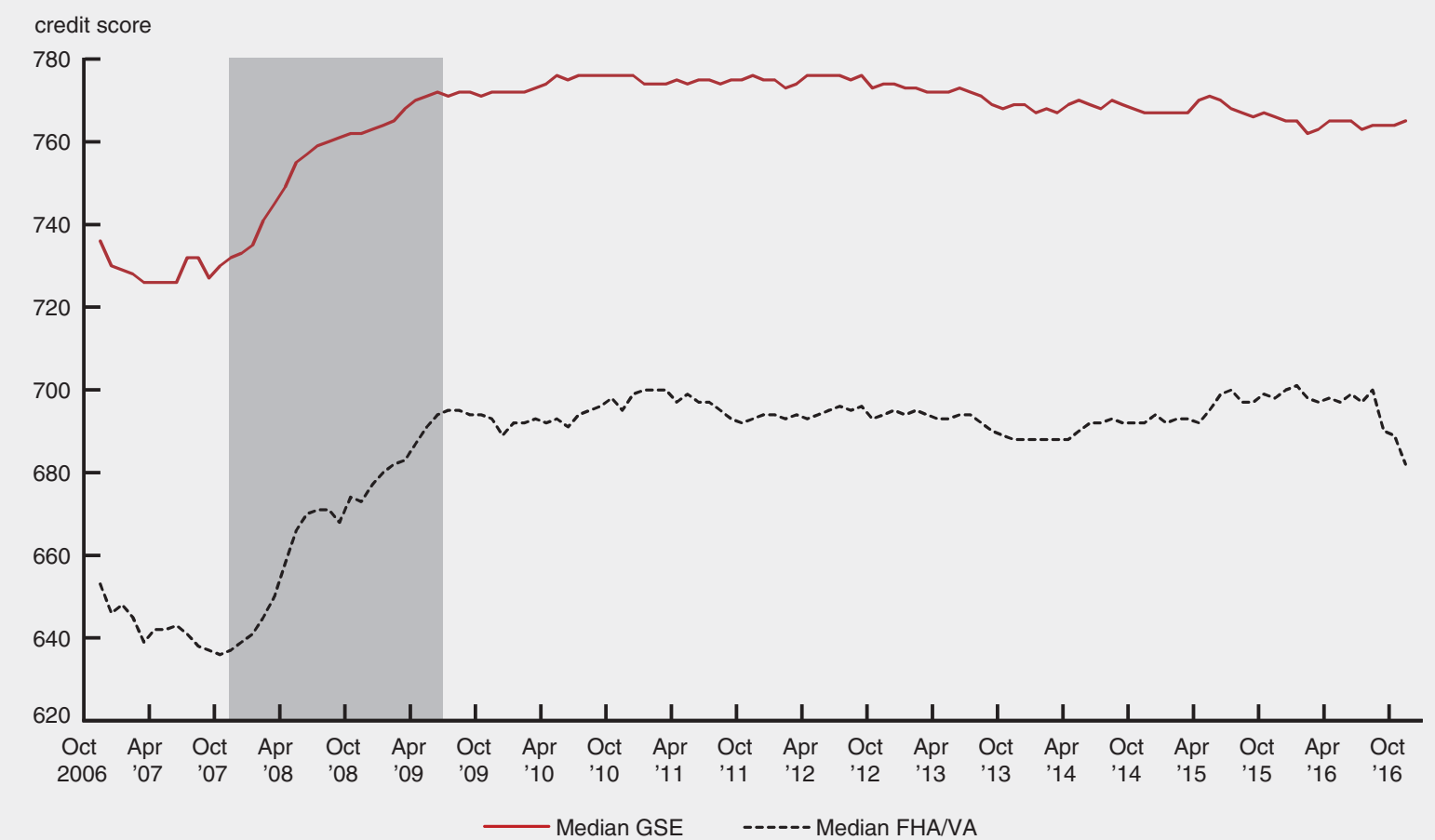

Source: McDash Analytics.

FIGURE 8

Success rate in obtaining credit

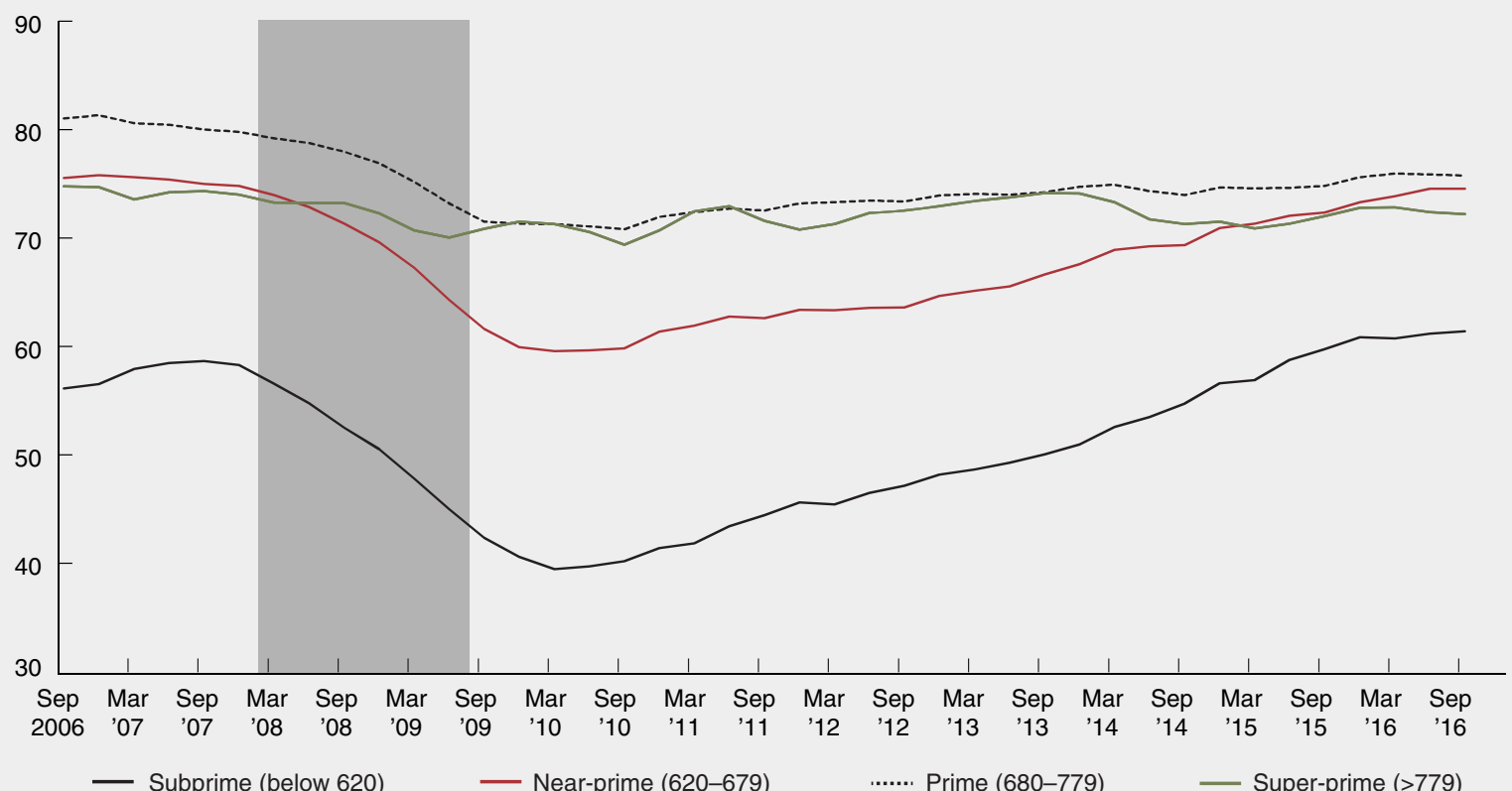

Subprime (below 620)

— Near-prime (620-679)

...... Prime $(680-779)$

Super-prime $(>779)$

Source: Equifax Credit Panel. 


\section{Fraction of constrained households over time}
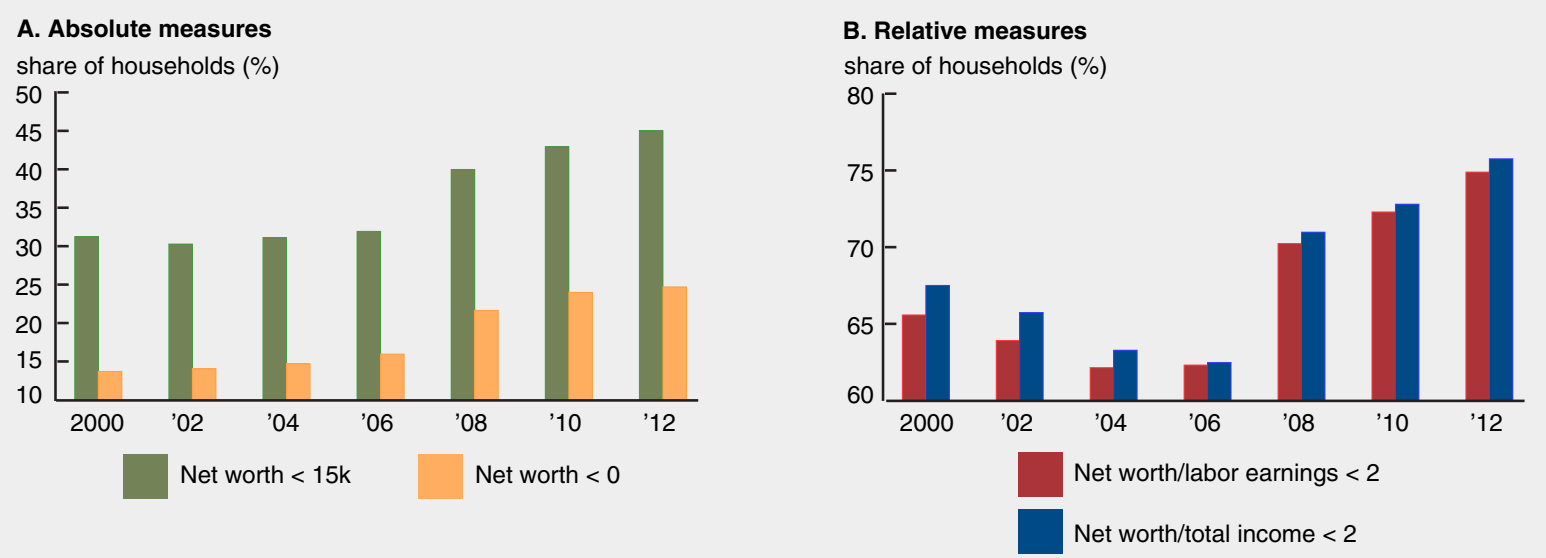

C. Borrowers below credit score threshold share of borrowers $(\%)$

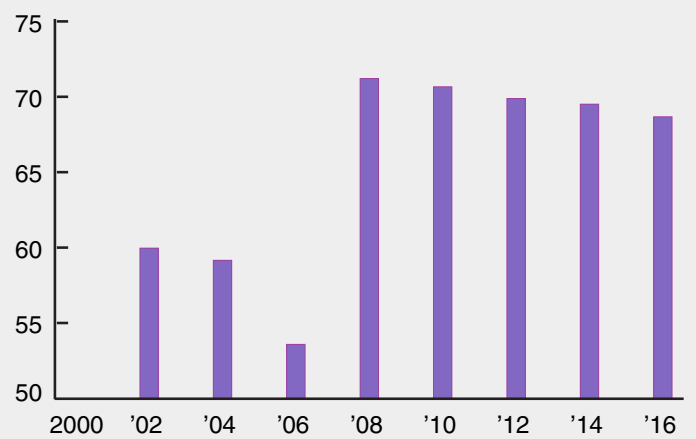

Sources: University of Michigan, Institute for Social Research, Pane/ Study of Income Dynamics; and Equifax Credit Panel.

the Veterans Administration (VA). The same phenomenon is illustrated by a sizable dip in success rates of credit applications in figure 8, which includes not only mortgages but also auto loans and credit cards. This decline is especially pronounced for the lowest-credit-risk-score borrowers, who tend to be young and/or have low incomes. Altogether, this negative shock to the accessibility of credit likely contributed to the observed patterns of substantial slowdowns in consumption growth and expenditure rates, especially at the bottom of the wealth distribution.

The persistence of various measures of credit tightening mirrors changes in household constraints, as shown in figure 9 for several metrics. The top-left panel presents absolute measures of household wealth below a certain threshold. The top-right panel depicts measures of household wealth relative to earnings or income. The bottom panel captures the share of households whose credit scores are below the threshold commonly employed by mainstream financial institutions. All of these measures paint the same picture and tell us that the share of constrained households increased dramatically with the onset of the Great Recession and showed no signs of decline through 2012. Since current models do not explain the slow recovery of consumption with simply a large fraction of poor households, the persistence of these constraints means that this channel could hold particular promise in bringing existing models in line with realistic consumption dynamics. 
TABLE 7

Annualized changes in employment variables over 2004, 2006 net worth quintiles

\begin{tabular}{|c|c|c|c|c|c|c|c|c|c|c|c|c|}
\hline & \multicolumn{3}{|c|}{ Worked last year } & \multicolumn{3}{|c|}{ Hours if worked } & \multicolumn{3}{|c|}{ Unemployed last year } & \multicolumn{3}{|c|}{$\begin{array}{c}\text { Head earnings } \\
\text { if worked }\end{array}$} \\
\hline & 04-06 & 06-10 & $\Delta$ & 04-06 & 06-10 & $\Delta$ & 04-06 & 06-10 & $\Delta$ & 04-06 & 06-10 & $\Delta$ \\
\hline All & -0.8 & -1.4 & -0.7 & 0.0 & -1.7 & -1.7 & -0.7 & 1.1 & 1.8 & 4.5 & 1.1 & -3.4 \\
\hline Q1 & -0.9 & -1.9 & -0.9 & 1.7 & -0.4 & -2.1 & -3.3 & 0.5 & 3.8 & 7.2 & 5.8 & -1.3 \\
\hline Q2 & -1.4 & -1.3 & 0.1 & 0.4 & -2.0 & -2.4 & -0.2 & 1.2 & 1.4 & 4.4 & 2.7 & -1.8 \\
\hline Q3 & -0.7 & -1.1 & -0.4 & -0.7 & -1.5 & -0.9 & 0.7 & 1.0 & 0.4 & 4.2 & 1.5 & -2.6 \\
\hline Q4 & -0.4 & -1.3 & -0.8 & -0.3 & -1.9 & -1.6 & 0.5 & 2.0 & 1.5 & 5.3 & 1.5 & -3.8 \\
\hline Q5 & -0.5 & -1.8 & -1.3 & -0.7 & -2.5 & -1.9 & -1.2 & 0.9 & 2.1 & 3.8 & -1.3 & -5.0 \\
\hline
\end{tabular}

Notes: Changes in working status are expressed as percentage point changes. Hours conditional on working are expressed as percentage changes.

Source: University of Michigan, Institute for Social Research, Panel Study of Income Dynamics.

\section{Changes in earnings risk}

Table 7 discusses changes in some statistics of the labor market by net worth quintiles. First, it shows that unemployment increased during the Great Recession and especially so for those in the bottom wealth quintile. Second, it highlights that there were also large changes in hours and the fraction of people working and that both are U-shaped in wealth quintiles. In the baseline models, unemployment is the only labor market dynamic that changes (exogenously) during the cycle and does so independently of one's wealth level. Thus, the labor market dynamics of the model abstract from important features of labor supply.

Other studies have also found that earnings conditional on employment exhibit different dynamics over the business cycle. For instance, Guvenen, Ozkan, and Song (2014) find that the left-skewness of earnings shocks is strongly countercyclical: During recessions, large upward earnings movements become less likely, whereas large drops in earnings become more likely. KS and KMP do not account for these important dynamics. The fact that negative earnings shocks become more likely in a recession is another force reducing consumption and increasing savings and might help bring the consumption response to aggregate shocks in the model more in line with the data.

This asymmetric increase in negative earnings risk during downturns holds promise in explaining the persistently languid consumption growth after the Great Recession, particularly among the poorest households, in addition to the initially steep decline. For example, Pistaferri (2016) runs regressions on changes in wealth and disposable income using pre-2008 aggregate data to predict consumption responses and then extrapolates these for the post-2008 period. He finds that consumption has recovered significantly more slowly than would be expected based on the historical data (a finding corroborated in our figure 1), but that accounting for household leverage and consumer confidence appears to explain the entire gap between observed and extrapolated trends. While the influence of the deleveraging process on reduced consumption has probably softened, Pistaferri finds that factors influencing consumer confidence have not. In particular, pessimism is strongest amongst the lowest quartile of the income distribution who report worse expectations and increased uncertainty concerning financial conditions. These households also exhibit a permanent rise in the expected probability of job loss, not unlike the long-lasting aversion to financial risk documented among households who experienced the macroeconomic shock of the Great Depression (Malmendier and Nagel, 2011). This indicates that the recession could be seen as being characterized by both permanent negative shocks to income and persistent increases in income uncertainty (De Nardi, French, and Benson, 2012). The prevalence of this pessimism among the poorest households underscores the importance of accounting for earnings dynamics in models of household heterogeneity. 


\section{Conclusion}

This article highlights a number of theoretical and empirical reasons established by earlier literature for the importance of household heterogeneity in understanding macroeconomic responses to shocks. In particular, we focus on identifying households who are constrained in their consumption choices. These households typically have a high marginal propensity to consume. Their prevalence in the economy and the nature of their constraints have a sizable impact on consumption dynamics.

While incorporating a realistic degree of wealth heterogeneity is crucial for generating plausible consumption responses, we argue that the role of constraints cannot be adequately captured by only having a large share of households with no wealth before a recession. This is particularly true in the case of slowdowns like the Great Recession, which delivered a strong negative shock not just to earnings, but also to wealth itself. We show that accounting for shocks to different types of wealth may also help explain consumption responses in the middle of the wealth distribution. Also, it is important to take into account supply-side changes in the availability of credit, which may further amplify the magnitude of the consumption response, especially among younger and less wealthy households. Finally, changes in the nature of earnings risks during booms and expansions should be taken into account.

\section{NOTES}

${ }^{1}$ We recently published short summaries of this work in the Chicago Fed Letter (available online, https://www.chicagofed.org/ publications/chicago-fed-letter/2018/392) and on VoxEU.org (available online, https:/voxeu.org/article/ household-inequality-and-consumption-response-shocks).

${ }^{2}$ We calculate similar results to KMP. See their paper for a comparison between aggregates in the PSID and National Income and Product Accounts.

${ }^{3}$ These are restricted-use data. See Lee and van der Klaauw (2010).

${ }^{4}$ Tables 1, 2, and 4 are calculated by the authors from the PSID following the computations by KMP.

${ }^{5}$ Recall that these statistics are derived from a representative panel of working-age households. Thus, they will differ from population-wide estimates that comprise NIPA data.

${ }^{6}$ Credit score refers to the Equifax 3.0 Risk Score. The Equifax 3.0 model score ranges from 280 to 850 . As with FICO scores, higher score values are associated with lower expected likelihood of default. Additional details are available online, https://help.equifax.com/app/answers/detail/a_id/244/noIntercept/.

\section{REFERENCES}

Bhutta, Neil, and Benjamin J. Keys, 2016, "Interest rates and equity extraction during the housing boom," American Economic Review, Vol. 106, No. 7, July, pp. 1742-1774. Crossref, https://doi.org/10.1257/ aer. 20140040

Campbell, Jeffrey R., and Zvi Hercowitz, 2018, "Liquidity constraints of the middle class," Federal Reserve Bank of Chicago, working paper, No. 2009-20, revised February 2018, available online, https://www.chicagofed.org/publications/working-papers/2009/wp-20.

Case, Karl E., John M. Quigley, and Robert J. Shiller, 2013, "Wealth effects revisited 1975-2012," Critical Finance Review, Vol. 2, No. 1, pp. 101-128. Crossref, http://dx.doi.org/10.1561/104.00000009

De Nardi, Mariacristina, Eric French, and David Benson, 2012, "Consumption and the Great Recession," Economic Perspectives, Federal Reserve Bank of Chicago, Vol. 36, No. 1, pp. 1-16, available online, https://www.chicagofed.org/publications/economic-perspectives/2012/1q-denardi-french-benson. 
Guerrieri, Veronica, and Guido Lorenzoni, 2017, "Credit crises, precautionary savings, and the liquidity trap," Quarterly Journal of Economics, Vol. 132, No. 3, August, pp. 1427-1467. Crossref, https://doi.org/10.1093/qje/qjx005

Guvenen, Fatih, Serdar Ozkan, and Jae Song, 2014, "The nature of countercyclical income risk," Journal of Political Economy, Vol. 122, No. 3, June, pp. 621-660. Crossref, https://doi.org/10.1086/675535

Kaplan, Greg, and Giovanni L. Violante, 2014, "A model of the consumption response to fiscal stimulus payments," Econometrica, Vol. 82, No. 4, July, pp. 1199-1239. Crossref, https://doi.org/10.3982/ECTA10528

Krueger, Dirk, Kurt Mitman, and Fabrizio Perri, 2016, "Macroeconomics and household heterogeneity," in Handbook of Macroeconomics, John B. Taylor and Harald Uhlig (eds.), Vol. 2, Amsterdam: Elsevier B. V. I North-Holland, pp. 843-921. Crossref, https://doi.org/10.1016/bs.hesmac.2016.04.003

Krusell, Per, and Anthony A. Smith, Jr., 1998, "Income and wealth heterogeneity in the macroeconomy," Journal of Political Economy, Vol. 106, No. 5, October, pp. 867-896. Crossref, https://doi.org/10.1086/250034

Lee, Donghoon, and Wilbert van der Klaauw, 2010, "An introduction to the FRBNY consumer credit panel," Federal Reserve Bank of New York, staff report, No. 479, November. Crossref, https://dx.doi.org/10.2139/ Ssrn. 1719116

Malmendier, Ulrike, and Stefan Nagel, 2011, "Depression babies: Do macroeconomic experiences affect risk taking?," Quarterly Journal of Economics, Vol. 126, No. 1, February, pp. 373-416. Crossref, https://doi.org/10.1093/qje/qjq004

Meyer, Bruce D., and James X. Sullivan, 2013, "Consumption and income inequality and the Great Recession," American Economic Review: Papers and Proceedings, Vol. 103, No. 3, May, pp. 178-183. Crossref, https://doi.org/10.1257/aer.103.3.178

Pistaferri, Luigi, 2016, "Why has consumption remained moderate after the Great Recession?," Stanford University, working paper, October.

University of Michigan, Institute for Social Research, Survey Research Center, 2017, Panel Study of Income Dynamics, public use data set, Ann Arbor, MI, available online, https://psidonline.isr.umich.edu/. 
Gene Amromin is a vice president and the director of financial research, Mariacristina De Nardi is a senior economist and research advisor, and Karl Schulze is a senior research assistant in the Economic Research Department at the Federal Reserve Bank of Chicago. De Nardi is also a faculty research fellow at the National Bureau of Economic Research (NBER). The authors are grateful to Dirk Krueger, Fabrizio Perri, and Kurt Mitman for providing some of their graphs, some of their codes for comparison, and for helpful discussions. They thank Francisco Buera, Spencer Krane, and Marcelo Veracierto for insightful comments and suggestions. The views expressed herein are those of the authors and do not necessarily reflect the views of the Federal Reserve Bank of Chicago or the NBER.

\section{(C) 2018 Federal Reserve Bank of Chicago}

Economic Perspectives is published by the Economic Research Department of the Federal Reserve Bank of Chicago. The views expressed are the authors' and do not necessarily reflect the views of the Federal Reserve Bank of Chicago or the Federal Reserve System.

Charles L. Evans, President; Daniel G. Sullivan, Executive Vice President and Director of Research; Anna L. Paulson,
Senior Vice President and Associate Director of Research; Spencer Krane, Senior Vice President and Senior Research Advisor; Daniel Aaronson, Vice President, microeconomic policy research; Jonas D. M. Fisher, Vice President, macroeconomic policy research; Robert Cox, Vice President, markets team; Gene Amromin, Vice President, finance team; William A. Testa, Vice President, regional programs; Marcelo Veracierto, Senior Economist and Economics Editor; Helen Koshy and Han Y. Choi, Editors; Julia Baker, Production Editor; Sheila A. Mangler, Editorial Assistant.

Economic Perspectives articles may be reproduced in whole or in part, provided the articles are not reproduced or distributed for commercial gain and provided the source is appropriately credited. Prior written permission must be obtained for any other reproduction, distribution, republication, or creation of derivative works of Economic Perspectives articles. To request permission, please contact Helen Koshy, senior editor, at 312-322-5830 or email Helen.Koshy@chi.frb.org.

ISSN 0164-0682 